FAIR RENT AND LEGAL FICTION 


\section{FAIR RENT \\ AND LEGAL FICTION}

Housing Rent Legislation in a

Capitalist Society

\section{PIERS BEIRNE}


(C) Piers Beirne 1977

Softcover reprint of the hardcover 1st edition 1977

All rights reserved. No part of this publication may be reproduced or transmitted, in any form or by any means, without permission.

\author{
First published 1977 by \\ THE MACMILLAN PRESS LTD \\ London and Basingstoke \\ Associated companies in Delhi Dublin \\ Hong Kong Johannesburg Lagos Melbourne \\ New York Singapore and Tokyo
}

ISBN 978-0-333-21509-8 ISBN 978-1-349-15821-8 (eBook)

DOI 10.1007/978-1-349-15821-8

Typeset in IBM Baskerville by

PRE F ACE LTD

Salisbury, Wiltshire

This book is sold subject to the standard conditions of the Net Book Agreement.

The paperback edition of this book is sold subject to the condition that it shall not, by way of trade or otherwise, be lent, resold, hired out, or otherwise circulated without the publisher's prior consent in any form of binding or cover other than that in which it is published and without a similar condition including this condition being imposed on the subsequent purchaser. 


\section{CONTENTS}

List of Statutes vii

List of Tables $\quad$ ix

Preface $\quad$ xi

1. THE SOCIOLOGY OF LAW: A SUITABLE CASE FOR TREATMENT

Introduction: A Shotgun Wedding 1

The Sociological Tradition: Durkheim and Weber 8 Emile Durkheim $\quad 8$

Durkheim's Sociology of Law 19

Max Weber (1864-1920) 26

Weber's Sociology of Law 34

Social Science Information and Legal Philosophy: the Institutional Connection

2. THE HOUSING QUESTION 1900-70: PRODUCTION AND LEGAL REPRODUCTION

Introduction 51

Ground and Housing Rent: an Equivalence 56

The Background: Rent and the Relative Autonomy of the State 66

State Intervention in the Rent Bargain $\quad 76$

Housing Rent Legislation 1919-45 83 
Rent and Tenure Post-1945 $\quad 97$

Council Rents $\quad 101$

Owner Occupation 107

The Social Control of Housing Rent 126

3. FAIR RENT AND LEGAL FICTION: HOUSING FINANCE AND THE HOUSING FINANCE ACT

Preamble

The Act

Fair Rent

Scarcity

154

Comparables

158

Gross Values

159

Cost

Needs, Rebates and Allowances

Subsidies and Owner Occupation

Opposition

4. HOUSING RENT LEGISLATION AND THE FRACTIONS OF CAPITAL

The Problem: the Situation of the Housing Finance Act

Housing Rent and the Fractions of Capital

Rent Legislation and the Housing Finance Act:

Conclusions

Appendix

1. Fair Rents and Improvements Grants

2. A Marxist Theory of Housing Need

3. The Rent Act 1974

Notes and References

Bibliography 


\section{LIST OF STATUTES}

Liverpool Building Act 184271

Public Health Act 184871

Nuisances Removal Act $1855 \quad 71$

Torrens Act $1868 \quad 73$

Public Health Act $1875 \quad 73$

Housing of the Working Classes Act 189074

Public Health (Amendment) Act 189074

Acquisition of Small Dwellings Act 189974

Housing of the Working Classes Act 1903 74-5

Housing, Town Planning \&cc., Act 190975

Increase of Rent and Mortgage Interest (War Restrictions) Act 1915 78-80, 199, 220

Addison Act 1919 81-2

Increase of Rent and Mortgage Interest (Restrictions) Act 191983

Increase of Rent and Mortgage Interest (War Restrictions) Act $1920 \quad 85-6$

Increase of Rent and Mortgage Interest Restrictions Act 1923 87-8

Chamberlain Act $1923 \quad 87$

Prevention of Eviction Act $1924 \quad 87$

Wheatley Act 192487

Rent and Mortgage Interest (Restrictions) Act 1933 91-2

Increase of Rent and Mortgage Interest (Restrictions) Act 1939 96, 98

Furnished Houses (Rent Control) Act 1946 97-101, 128-30

Landlord and Tenant (Rent Control) Act $1949 \quad 129$

Housing Repairs and Rents Act $1954 \quad 112$

Rent Act 1957 113-120

Housing Purchase and Housing Act 1959119 
viii LIST OF STATUTES

Agriculture Act $1958 \quad 120$

Tribunals and Inquiries Act 1958 130-1

Rent Act 1965 124-5, 129-30, 133-8, 143, 154-8, 166

Rent Act $1968 \quad 130,135-8,150-1$

Housing Act 1969150

Rent (Scotland) Act 1971 157-8

Housing Finance Act 1972 xv, 103, 120, 130, 137-80, $181-204$

Furnished Lettings (Rent Allowances) Act $1973 \quad 150$

Rent Act 1974 211-13 


\section{LIST OF TABLES}

1. Houses erected in Great Britain, 1919-39 84

2. Local authorities: gross loan debts outstanding, 1962-74

3. Expenditure of local authorities out of revenue and special funds, 1962-74

4. Stock of dwellings in the United Kingdom, 1900-74: by tenure

5. Large companies and employees' housing rent assistance

6. Houses erected in Great Britain, 1945-60

7. Houses erected in Great Britain, 1954-70

8. Dwellings-households shortage in England, Wales, and Scotland, 1959-64

9. Changes in the capital value of urban houses, 1939-73

10. Registered rents compared with previous rents, 1966-70: percentages of totals

11. Actual registered rents and actual previous rents, 1966-70

12. Percentage change in registered rents, 1966-9

13. Rent registration: average registered rents and change on previous rents

14. Rent registration: average registered rents and change on previous rents

15. Department of the Environment estimates of average rent increases under the Housing Finance Act

16. Local authority dwellings: estimation of age of stock 
17. Average construction cost of local authority dwellings

18. Seven British construction companies: accounts and vital statistics, 1968-71

19. Loans for house purchase: main institutional sources, 1960-72

20. Rents of offices with planning permission in London, 1960-71

21. The property speculators: accounts, $1968-70$

22. Slum clearance and house improvements, 1956-70

23. Average weekly rents of local authority dwellings, 1964-73 


\section{PREFACE}

Prisons are built with stones of law, Brothels with bricks of religion.

William Blake

From Plato to Hegel a persistent theme of social philosophy has been a concern with the nature of rule-governed behaviour. Our concern here is with the speciality of 'legal' rules. According to the colouring of the premises a legal rule has been variously understood as a cohesive force which promotes and protects collective social values, as an impartial arbiter of competing interests, as a barometer of social change, and as a weapon in the armoury of the ruling class. The whorehouse theory of law, and Michael Bakunin's dictum that every command slaps liberty in the face, attest to the inexhaustible supply of riches in this particular area of intellectual endeavour. However, whilst social philosophy has tended to situate legal rules in the broader epistemologies associated with the set of conceptual questions generated by the Hobbesian problem of order, more recent trends have attempted a methodological reversal. With the monopoly by classical and academic sociologies of what is perceived as the 'social', elements of social formations have been compartmentalised, with the result that social life and social events appear as transient or indeterminate existences independent of their historical causation. Classical sociology is a doctrine which proclaims that history does not exist, yet simultaneously it draws its knowledge from historical events much the same as a bloated maggot draws its life force from its dead victim.

A spectre has been haunting jurisprudence in the twentieth 
century: the spectre of social science. What was formerly an insular and uncontaminated craft speciality is gradually being incorporated into the domain of social theory. In effect jurists now recognise and affirm the Hegelian notion that one does not have to be a cobbler to know if one's shoes fit. Nevertheless to characterise the demise of juristic autonomy in this manner would be to conceal the origins of the general process in which all intellectual inquiry must either become servile to the march of science or else suffer reduced professional credibility and smaller research grants. The value of an historical dimension to the social-scientific movement in the study of legal rules is that the possibility arises of demonstrating that the paradigm to which the emerging orthodox subscribes is directly a product of the epistemological imperatives established by the social theory of nineteenthcentury sociologists. What to the participants in this paradigm may appear as new and significant developments in the production of knowledge, to those with other intentions may assume an essential continuity with bourgeois political practices. The major task of the first chapter in this book is to establish that such practices are constitutive of the limited achievements of a particular intellectual ancestry. In the United Kingdom this latter is seen as a unique matrix which combines elements of classical sociology, Anglo-Saxon jurisprudence, and American realism.

What does such a critique require? Let me say first what it does not require. It does not require yet another piecemeal empirical investigation of the social injustices perpetrated by legal rules in a bourgeois society. Much of the developing movement in the United Kingdom can be traced to the altruistic quest for reform of the most flagrant abuses endemic to such a society. A major element in the orthodox paradigm therefore consists of a positivist epistemology which treats legal rules as non-problematic social facts. To begin with such a critique requires an understanding of how the dominant paradigm necessarily reflects the dominant social forces which produce and condition it. In the final analysis the only criterion of adequate theory is its ability to explain the empirically real. Other systems of thought should of course be used provided that the logical fields within 
which their propositions have pertinence are clearly recognised, and with the extra condition that one remembers that there are finite boundaries which no academic or bourgeois theorist may transcend without destroying his very essence. Bourgeois 'ideology' is a system of thought which suffers from the theoretical limits prescribed by the practical deficiencies of capitalist social formations. Bourgeois social theory both affirms the constraining power of social facts and at the same time denies its own association with them. It is a world view whose limits are wedded to the development of and contradictions within the formation in which it resides.

This is not to argue that bourgeois ideologists are consciously engaged in promulgating the actual. Some are committed to its reformation. The fact that it has practical uses for a particular class argues strongly that it contains some kernel of truth. But bourgeois ideology is by definition incapable of transcending bourgeois social formations. It is therefore always the removal of the unacceptable veneer of capitalism which is championed by such ideologues, and never the core dynamic of that formation itself. It could not be otherwise for it is precisely such demands which delimit it as bourgeois ideology. But this is merely to restate the truism that the degree of social change which is believed necessary to effect certain theoretical objects is largely immanent in the presuppositions on which those objects are constructed.

Radical dialogue is itself limited to the extent that it counterposes one inadequate system of thought with yet another system based on a priori principles. It is indeed such a distortion of Marxist philosophy which changes it from revolutionary critique to dogmatic inertia. As Sartre has observed: 'The open concepts of Marxism have closed in. They are no longer keys, interpretative schemata; they are posited for themselves as an already totalised knowledge.' (Sartre, 1968, p. 27). Marx himself consistently stated that there was no a priori relation between production and the social and political structures, and in The German Ideology he stressed the openness of this relation:

...definite individuals who are productively active in a definite way enter into these definite social and political 
relations. Empirical observation must in each separate instance bring out empirically, and without any mystification and speculation, the connection of the social and political structures with production (Marx, 1974, p. 46).

Both classical sociology and authoritarian socialism inevitably portray the relation of base to superstructure in historical materialism as essentially unilinear. On the part of the former this is frequently not simply a misconceived reaction to what it perceives as the political correlatives of Marxist philosophy but also an assault on the vulgar economism which determines law as a mere reflection of the condition of the class struggle and the relations of production. Bourgeois ideology's attempt to expose the naivety of 'conspiracy' models acquires a certain degree of sophistication within this particular vein of criticism. Max Weber's erudite treatment of Stammler is an excellent illustration. This, then, is able to point to the repressive tendencies inherent in the Stalinist interpretation of such projected Marxist categories as the 'transitional phase' and the 'dictatorship of the proletariat', while simultaneously avoiding serious treatment of the revolutionary implications of what is now generally termed 'Hegelian Marxism'. The authoritarian socialism which flowed naturally from a doctrinal complex responsible for the betrayal of the Kronstadt sailors and the anarchist Nestor Mahkno - a strategy which Lenin learned from Tkachev and Nechayev rather than Marx - this, for its part, uses the legal apparatus with as much partiality and vehemence as the bourgeois-democratic State from which it seeks to differentiate itself.

In this context it is appropriate to distinguish between the two principal levels at which law operates in class societies. On the one hand it is used as an overtly repressive mechanism for ensuring the continued legitimation of a definite mode of production and of the dominance of a definite ruling class. At this level law tends to become more visible in moments of crisis. But underpinning this esoteric presence is the orthodox presentation that law is an inevitable and healthy feature of civilised existence. This is not to argue that law in practice automatically reflects the interests of the dominant social 
forces, whether in a subtle manner or otherwise. Indeed in clas̀s societies some crucial legislative pieces have been enacted as the outcome of major inter-fractional conflict - the factory legislation of England in the 1840s is a pertinent illustration, and to a certain extent so also is the rent-control legislation introduced in England and Wales in 1915. However, law operates at a second, perhaps even more pervasive, level. This is at the level of ideological domination, a form of coercion where the dominant social forces seek to hegemonise global consciousness. Here law affirms existing social relations so as to perpetuate the economic mode of production. Here law is abstracted from these relations and appears as a fetishised event which seemingly stands above them. Law derives from the articulation of particular interests, and its appearance in popular consciousness as the summation of the universal interest in no small way explains the apparent staying power of the social order of western capitalist economies.

Several considerations influenced the production of this study. Firstly, it sprang from a practical involvement with squatters' movements and tenants' associations in London and the north-east of England at the time of the Housing Finance Act of 1972. There was a widespread feeling that despite the bankruptcy of the national movement, this Act could nevertheless successfully be opposed through the medium of 'community politics'. The feeling was short-lived. The capitalist State was easily able to quash a series of localised oppositions to the Act. The analysis of the capitalist State, in both its national and local manifestations, has attained the position of a boom industry. Gramsci, Poulantzas and Miliband are currently academic household names in all disciplines of social science. Most such radical analyses have been firmly rooted in the Marxist tradition, and there appear to be two predominant causes for the urgency of this trend: the world-wide elaboration in the authority of the political; and the imputed embryonic nature of the Marxist theory of the State.

This latter assertion is pivotal to the heated debate which has focused on the status of Marx's early writings (that is, those produced between 1839 and 1845). The Parisian 
school, led by Louis Althusser (for many Marxists the functional equivalent of Talcott Parsons), unites on the key issue that the Marx of the period which stretches from the doctoral dissertation of 1839 to The German Ideology (1845) is a Marx still enmeshed in the attractive but mystifying web of German idealist philosophy. What is clearly at stake in this issue is the very meaning of Marxism both as social theory and as political movement. Here it is asserted that the 'young' Marx is immature, unscientific and therefore to be discarded: as an ideologist he is unable to think himself through to his own intellectual production. If Marx did not concern himself with the 'superstructure' in general after 1845 then a necessary implication is that a Marxist approach to the study of legal rules is excluded on a priori grounds. If correct what merely appears as a reductio ad absurdum results in the reformist political practices embodied in the 'Marxism' of the Second International. If Marxism is unable for a priori reasons to demonstrate the dependence of capitalist social formations on a strictly articulated legal manipulation, then exactly to that extent it reduces itself as a vehicle of revolution.

On the other hand it is asserted that the young Marx is a Marx whose main concerns are with alienation and justice and that these are more revolutionary objects than the problematic established by the historical materialism of the post-1845 era. Gouldner has succinctly summarised the consequences of the two sides of this division and the syndrome of their correlated commitments:

The mission of a Hegelian Critical Marxism is to safeguard revolutionary purpose and elan; the mission of an antiHegelian Scientific Marxism is to protect the organisational instrument and its future options. It is thus easier for revolutionaries out of power to be Hegelians, whilst those in power will find congenial the prudence of an anti-Hegelian Marxism (Gouldner, 1973, p. 439).

Although Gouldner unfairly attributes allegiance to the respective positions on the basis of political opportunism, nevertheless his general point is incisive. For present purposes 
it is important that the majority of Marx's writings on State and law were contained in the early period. Only at this time, Gouldner's Scientific Marxist would retort, Marx was not yet Marx. This is not to dispute Marx's undoubted idealism between 1839 and 1845 , but to take issue with the scientific interpretation of its meaning. The ideological component in the work of the young Marx (particularly in 1843-4) is as significant for social revolution as the scientific paradigm is for pointing out the political fallacy of such theses as Luxemburg's 'inevitable collapse'. In other words the position of the young Marx has implications for a different order of revolutionary practice.

This piece must also be seen as a reaction to the emergence in the United Kingdom of a 'sociology of law' circa 1970. That this is such a recent phenomenon compared with events in the United States and parts of Europe (principally Germany, Italy, France and Scandinavia) is all the more startling since notions of legal rules were central to the sociologies of both Durkheim and Weber. In part this sociological omission has been determined by the autonomy and isolation of the legal profession in the United Kingdom. What attempts there have been to situate law in its 'social context' have been grossly abstract (analytical philosophy), unconcerned with capitalist social formations (legal anthropology), or correctional (positivist criminology). The result of this nexus is that the paradigm to which the sociólogy of law in the United Kingdom aspires is an ambiguous mixture of this heady matrix. The nature of this embryo is by no means unique within social science: since the 1930 s social theory has been dominated by emigré and mainly conservative intellectuals (such as Wittgenstein, Popper, Berlin, Eysenck, Gellner and Balogh). Britain is unique among advanced capitalist formations in that it has produced neither a classical sociology nor a national Marxism (Anderson, 1968). What is profoundly lacking from social theory is an explicit theoretical formulation. We must therefore look to the nature of the contemporary empiricism by assessing the worth of those imported models which have historically determined it. Such an exercise is necessarily selective. Since the trend is undoubtedly towards a reliance on sociological definitions I 
shall concentrate almost exclusively in the first chapter on the nature of legal rules as they are perceived and practised by classical and academic sociology. To a large extent this latter is synonymous with the respective epistemologies bequeathed by Emile Durkheim and Max Weber. This exercise will at least serve an iconoclastic function. Implicitly it will be predicated on a methodology far more critical in its analysis of legal rules in class societies.

This study was largely written in 1973, and although I am all too conscious of the gross errors which it contains I have nevertheless resisted the temptation for extensive revision. Since then major advances have been made in the general area of the political economy of housing (David Harvey, Manuel Castells, the Kapitalistate group, the Conference of Socialist Economists). There has also been a renewed interest in critical theories of law, and we can predict both the overdue popularity of Pashukanis and the final rejection of Renner. My concern at the time, however, was neither with the housing process as a whole nor even with housing rent legislation as such: in a strong sense, therefore, the analysis of housing rent legislation in this text is almost incidental to the major questions which are posed. It arose as a response to broader concern with formal, state law as a vehicle of domination.

This traditional object of anarchy thus raises a note of confession. My present preference, in the opportunistic advance from bourgeois social theory to unsophisticated Marxism, is for what Feyerabend has aptly characterised as the basis of an anarchist epistemology: methodological pluralism (Feyerabend, 1975). Science and systems of thought are much closer to myth than scientific philosophy is prepared to admit. Science is not at all the innocuous, ethically free production which its adherents purport it to be. Indeed it would be equally sterile to argue for a rigid distinction between 'science' and 'ideology'. If scientific argument merely resulted in dogmatism - the elevation of a conceptual structure to scientific status is after all only done in the belief that science is the correct Weltanschauung - and ideological argument in scientific failure, then the matter would be quite straightforward. But the problem is that science is but one stage in the developing structure of human thought, a stage 
which is exclusively confined to four hundred years of western civilisation. Science, in common with voodoo and religion, is itself in the end an ideological venture. As Marcuse has imputed to what Max Weber may really have thought of technological rationalisation: 'And this you call reason' (Marcuse, 1972, p. 226). Science elects to look at particular aspects of the universe in very particular, constraining ways. The more scientific an argument, the more it sheds its revolutionary potential in its confrontation with practice.

The solution to this relativistic impasse is the adoption of an avowedly ideological position. However, this is simply to admit that scientific theories either explicitly or else by assumption contain ideological premises. The advancement of scientific knowledge as a neutral production is in practice to ensure that external valuations are imposed on it. To hold the reverse would be to fail to see not only that all scientific theory is conceived within a definite social formation but also, and in common with social formations, that such theory is eventually falsified. The very decline of philosophical systems after Hegel conforms to the Master's insight that social formations and social knowledge are erected on a constant process of dialectical movement through contradiction. Everything is ultimately transcended. A rigid materialism is only one step further away from the infinite regress into which all epistemologies seem inevitably to slide. As with Greek philosophy after Aristotle, and German philosophy after Hegel, the solution to this invited nihilism must lie in the realm of ethical evaluation. This essay would therefore have been more rigorous had it been based from the outset on an eclectic brand of anarchism.

Many people have aided and abetted the completion of this study. My main source of encouragement and criticism has been Dave Byrne, and it is to him that I owe my greatest debt. Most invidiously I would like to extend my thanks to my parents, Stan Cohen, David Cormack, Dave Davies, Ken Foster, Nicholas Light, Martin Partington, Bob Roshier, Shaie Selzer, Ann Stewart, Jane Thompson and Jock Young. 